\title{
Consensus
}

Volume 28

Issue 1 Waterloo Lutheran Seminary Lutheran Life

Article 16

Lectures 1998-2001

5-1-2002

\section{The making of the Magdalen: preaching and popular devotion in the later Middle Ages}

Sherry Pember

Follow this and additional works at: http://scholars.wlu.ca/consensus

Part of the Practical Theology Commons

\section{Recommended Citation}

Pember, Sherry (2002) "The making of the Magdalen: preaching and popular devotion in the later Middle Ages," Consensus: Vol. 28 : Iss. 1 , Article 16.

Available at: http://scholars.wlu.ca/consensus/vol28/iss1/16

This Book Reviews is brought to you for free and open access by Scholars Commons @ Laurier. It has been accepted for inclusion in Consensus by an authorized editor of Scholars Commons @ Laurier. For more information, please contact scholarscommons@wlu.ca. 
to be examined within their ritual and liturgical context.

With this book, BeDuhn makes a very significant contribution to the field of Manichaean Studies by attempting to shift the focus of scholarly attention away from the abstract elements of Manichaean discourse to the concrete rituals and practices that defined the Manichaean identity. In doing so, BeDuhn has helped to clarify a movement that has tended to shock and to perplex so many early Christian and modern commentators.

Timothy Pettipiece

Wilfrid Laurier University

\section{The Making of the Magdalen: Preaching and Popular Devotion in the Later Middle Ages}

Katherine Ludwig Jansen

Princeton, NJ: Princeton University Press, 2001

408 pages, $\$ 30.95$ Softcover

Katherine Ludwig Jansen is Assistant Professor of History at the Catholic University of America, and this book is a revision of her doctoral dissertation. It endeavours to explain why, by the late medieval period, Mary Magdalen had transformed from a shadowy gospel figure to the most popular female saint after the Virgin Mary. Key to this transformation, it argues, is the development of the Magdalen cult both through the lens of medieval preaching, and the responses of those who heard the friars' sermons.

The framework of this analysis begins with the opening of the Fourth Lateran Council in 1215, and concludes with the emergence of the Reformation in 1517 when preachers were confronted by the Protestant challenges to the cult of the saints. Jansen's study is geographically focussed in the Mediterranean regions of Provence and Italy. She claims that this is the setting where devotion to the Magdalen reached its pinnacle in Christendom.

Jansen's argument in this book is cumulative and is divided into four sections. The first section, "The Mendicant Magdalen" (49-142), outlines the development of the figure of Mary Magdalen fashioned by the late medieval mendicant preachers. Jansen suggests that through 
public preaching and hagiography the friars transformed the Magdalen into the "apostle of apostles" or copostolorum apostola, an exemplar of active and contemplative life. This paradigm was multifaceted and was appropriated to serve as a reflection for the life of the mendicants, monastic women, and laity. Further, through symbolic gender reversal, the mendicants identified themselves as the new Magdalens.

Part Two, "The Wages of Sin" (145-196), focuses on the licentious aspects of the Magdalen legend from which the mendicants estranged themselves. Both preachers and moralists emphasized this representation as a means to preach fervently on the evils of vanity, luxuria, prostitution, and the frailties of women. These sermons were aimed toward the amelioration of society and also served as a means of social control.

Part Three, "Do Penance" (199-244), analyses the friars' Magdalen as the pre-eminent symbol of penance. Jansen amalgamates mendicant preaching, the rise of refuges for prostitutes, and the Fourth Lateran Council's reformulation of the sacrament of penance as a means to account for the flourishing of Magdalen devotion in the Middle Ages. Jansen posits that Mary Magdalen became, not only the model of penance but, more importantly, the primary symbol of hope for all people, a transformation which explains much of her universal appeal.

The final section, "Responses" (247-336), turns to the reaction of those who heard the sermons or read the legendary accounts. Jansen argues that the friars' audiences actively responded to, imaginatively shaped, and resourcefully utilized images of Mary Magdalen for their own purposes. Moreover, she notes that women responded differently to the friars' preaching than men. While both genders called on the intercessory powers of the Magdalen in her role as an advocate for sinners, on the whole, women did not think that their renunciation of $\sin$ would save the souls of innocent men or civil society as the friars preached; rather, they believed that renouncing sins was a step toward personal salvation. Further, by the later medieval period Mary Magdalen's attributes resembled the Virgin Mary and she was considered a virgin and invoked as a mother. Magdalen's glorification in heaven provided hope for many women that lost virginity was not an insurmountable obstacle in the quest for salvation.

The Making of the Magdalen is a fascinating study that would be of interest to both scholars and non-scholars alike. It is extensively researched, skilfully written, and adeptly constructed. This book is an essential read for those persons interested in late medieval religion, 
history, popular Christian devotion, theology, literature, art, gender, or Mary Magdalen scholarship.

Sherry Pember

Wilfrid Laurier University

\section{Thomas Merton and the Monastic Vision}

Lawrence S. Cunningham

Grand Rapids, MI: Eerdmans, 1999

228 pages, $\$ 24.95$ Softcover

Given the overabundance of "Mertonia" that has emerged since his death in 1968, sorting through the books, articles, videos, tapes, monographs, etc., to obtain an accurate rendering and thoughtful analysis of Thomas Merton's life can be a daunting task indeed. Lawrence Cunningham has written a brief but thorough study of Merton's life and thought that offers an excellent introduction to his writings and influence in twentieth-century religious life.

Cunningham places Merton in both the context of the early monastic Fathers and Mothers, whose influence played an important role in his development as a monk, and in the context of the vast changes of the Second Vatican Council and the social and political upheavals of the 1960s. As committed as Merton was to peace issues and the civil rights movement, his involvement grew out of a profound engagement with monastic tradition and his life as a contemplative monk. Which brings me to Cunningham's thesis: "...the prolific works which flowed from Merton's pen and the impact that those writings and his person had and continue to have can only be understood against the background of his contemplative experience as a Trappist monk. Indeed...one cannot understand Thomas Merton if one does not understand him as a monk" (17).

Cunningham's treatment steers clear of hagiography. He paints a portrait of Merton that intermingles his less than holy moments-i.e., his pettiness towards his Abbot (James Fox) when he was refused travel, his (understandable, if not childish) tirades against the American Catholic hierarchy, his affair with "M," the nurse with whom Merton fell in love - with a profound engagement with his active mind and his contemplative vocation. Just as Merton himself did not cover up his 